Meta

Journal des traducteurs

Translators' Journal

\title{
Problems incorporated
}

Translation Management in an Industrial Environment

\section{Thomas Schneider}

Volume 29, numéro 4, décembre 1984

URI : https://id.erudit.org/iderudit/004049ar

DOI : https://doi.org/10.7202/004049ar

Aller au sommaire du numéro

Éditeur(s)

Les Presses de l'Université de Montréal

ISSN

0026-0452 (imprimé)

1492-1421 (numérique)

Découvrir la revue

Citer cet article

Schneider, T. (1984). Problems incorporated: Translation Management in an Industrial Environment. Meta, 29(4), 359-361. https://doi.org/10.7202/004049ar d'utilisation que vous pouvez consulter en ligne.

https://apropos.erudit.org/fr/usagers/politique-dutilisation/ 


\title{
PROBLEMS INCORPORATED TRANSLATION MANAGEMENT IN AN INDUSTRIAL ENVIRONMENT
}

\author{
T. SCHNEIDER
}

The exaggeration presumed to underlie the statement that 'translation management is an impossible task' is marginal. Rather, the quantum leap from the imponderabilities of real everyday situations to the ideal world precludes any near-term approximation of a stable and reasonable framework within which to fulfill the task.

An industrial environment, sometimes the envy of struggling small translation bureaus, is no exception to this. The sum of all problems seems to remain constant. And while some of the problems encountered and solutions proposed may of greater or lesser significance for other translation environments, they are by no means idiosyncratic.

Siemens AG is a large electrical/electronics firm with many subsidiaries abroad which has a spectrum range from components and medical instruments to large-scale telecommunications systems and power plants. More than half of the sales are realized abroad. Consequently, user documentation of print quality constitutes a large percentage of in-house translations, and indeed the Language Services Department (KSD) is of crucial importance to the export business. More and more countries insist on technology transfer to replace the old vendor/buyer role distribution with its "colonial" connotations. It no longer suffices to supply documentation in the vendor's language or even a supposed lingua franca like English.

This situation, however, also defines one of the basic problems of our translation work : a multitude of different technologies must be covered in several language by a limited number of translators. Keeping in mind that more than half of the products marketed by Siemens today were developed in only the last five years, and that the cycle of technological innovation is getting ever shorter, it is obvious that most of the texts encountered by the translators deal with very recently evolved high technology.

The demands on the qualifications of the translator are extremely high. Not only does he/she need superior competence in the two languages involved but he must have the technical background to understand the content of the documents he is to translate. Most of the KSD translators have degrees from universities or specialized translation schools, and still an additional "on-the-job- training" of two to three years is required. Highly qualified technical translators are rare; actually, one really needs a combination of engineering knowledge plus language skills resident in the same brain. Unfortunately, the salary range offered to translators is not adequate for the significance of the task.

In the past, translator training at universities has not always paid much attention to the most likely practical application, i.e. technical documents rather than literary texts. Therefore it is necessary for industry to contribute expertise to translator training in universities (as Siemens has been doing), by offering lectures, by supplying "live" texts, terminology, models for the translatory process, by accepting students for trainee- 
ships, etc. These efforts in improving the qualifications of future translators, however, certainly fall into the category of a snail-pace approximation of a better world.

But it would be extremely short-sighted to argue that since, due to the present recession, the demand for translation has decreased industry does not need to support translator training. We need a longer perspective; translation problems cannot be solved at the stage that the texts appear on a translator's desk.

Because of the subject matter involved, it is imperative that our translators keep up with new developments in their respective fields. The "cheapest" way is to supply a steady flow of technical literature and subscriptions to journals. Here, of course, a large industrial company has an advantage over small bureaus ; the presence of a large up-todate technical library and other services for information gathering, not to mention inhouse courses in new technologies, are most helpful. Such courses are expensive, but to neglect continuing training in a field that is so innovative would have disastrous effects.

Moreover, the qualification and motivation of the translators are the greatest assets a language services department has, and if for reasons of general economy or of administrative decisions the remuneration of translators cannot be upgraded beyond certain limits, it becomes even more important to pay attention to other motivating factors, and continuing education - coordinated with the person's individual interests and desires - is certainly one of them.

We had mentioned above that the translation task should not be viewed in isolation. A qualified translator is often confronted with texts that defy normal treatment, be it that they are illegible, unintelligible or of otherwise inadequate quality. His work is greatly hindered. The conclusion is obvious : a language services department must exert some influence on the original documents before they are to be translated. In our industrial setting, unfortunately, urgent in-house jobs cannot be refused because the original text could be improved upon. KSD has - by organizational definition - no jurisdiction over the way original documents are composed and can only use persuasion to achieve an improvement of the texts.

In order to improve the original documentation, Language Services has developed and instituted a course that teaches tech-writing engineers how to construct manuals and adhere to syntactic and lexical structures that make the content easier to understand. This course if offered as part of the continuing education for interested techwriters and engineers, and again falls into the category of slow approximation of the elusive goal.

At KSD, documents are usually translated into one language at a time. Therefore, the various language groups (English, French, Spanish, etc.) work quite independently of one another. When a translation order is received, the section chief usually picks the group of translators that is closest in subject area specialization and can handle the work load in the requested time frame. Translated texts are revised by an experienced senior translator, usually a group leader. Word processing is used wherever possible ; if graphics are required by the user they are added in a specialized word processing section of KSD.

Very large documents, e.g. manuals for telecommunications systems, have to be divided up between several translators. Here, of course, one of the problems is consistency. If the end user of the translated document finds the same device part or concept referred to by several different terms it can lead to operating errors with expensive consequences. One the the tools used to minimize this problem is the terminology data bank TEAM. For large tasks in specific fields, a subset of the data bank defined by the subject field and the language pair is prepared by the terminology section in cooperation with the translation section chief and made available either for direct query (for transla- 
tors working on a terminal) or on paper. For small items of needed information, translators will usually ask the terminologist assigned to the section.

An organizational problem arises from different priorities between translators and terminologists. Translators working with a tight deadline are not easily encouraged to document new terms encountered during the translation process; terminologists point out that researching terms and not documenting them for later use by other translators is extremely wasteful. Here, too, the process of mutual understanding is slow. Nevertheless, in spite of the great expense involved in operating the data bank it has proved to be an indispensable tool for our technical translators.

The most serious problem KSD (and any other translation service) is faced with arises from the uneven distribution of the translation work load, avalanches taking turns with summertime lulls, with a subsequent explosion of costs. On the one hand, KSD must be prepared for sudden peaks of urgent work, on the other hand, KSD - organized as a profit center - is required to work cost-effectively. If from one month to the next translation orders drop to half of the previous level, translators will be idle. The resulting losses cannot be covered indefinitely but the choice of remedies is limited. Translators are not a moth-ball fleet that can be called into service and retired at will. Using free-lance translators to handle over-flow work is not always possible either, be it because of the confidentiality of the material, be it because of the demanding high technology content involved or because of other specific user requirements (style, terminology, etc.).

As a steering mechanism, translation load planning has been instituted with all KSD customers. Unfortunately, considerable prophetic powers are required to extrapolate reliable figures about the type, language pair and volume of texts, and about the personnel needed over the next few years. There is little hope that this state of affairs will ever change.

The solution pursued by KSD is not to expand the translator staff to account for all eventualities but to work with a limited number of translators and to increase their productivity by supplying machine aids and terminology from various sources. Texts that can be translated externally will be farmed out to free-lancers (usually with inhouse revision). Eventually, sudden peak loads will be managed by using machine translation to support the available translation staff. But here, too, it's a long road to our Concrete Utopian world. 